\title{
THE DEFENSIVE EFFECT OF MEDICAL PRACTICE POLICIES IN MALPRACTICE LITIGATION
}

\author{
Mark A. HaLL* \\ I \\ INTRODUCTION
}

Killing Two Birds With One Stone

According to the prevailing discourse in health policy circles, America's medical system is in the grips of two "crises": one of health care spending and one of medical malpractice liability. Although this crisis mentality may result in part from uncritical acceptance of interest group dogma, to the extent that a crisis is in fact widely perceived, it has the quality of a selffulfilling prophesy: if doctors believe, rightly or wrongly, that malpractice suits are out of control, they will practice more defensively, which will further fuel rampant health care spending. ${ }^{1}$ Moreover, malpractice law may stand as a principal force in opposition to cost containment reforms: if the inflated practice norms of the past are enshrined in malpractice law precedents, then any physician who responds to cost containment incentives by treating patients less aggressively may be exposing herself to certain malpractice liability. ${ }^{2}$

Copyright (C) 1991 by Law and Contemporary Problems

* Professor of Law, Arizona State University.

This article is a revision of a report submitted to the Physician Payment Review Commission in January 1990 that evaluated an American Medical Association ("AMA") report entitled Legal Implications of Practice Parameters (Am Med Ass'n, 1990). Jim Blumstein, Randall Bovbjerg, Alice Gosfield, Timothy Jost, and Tom Metzloff provided insightful information and analysis. Mark Siegel provided valuable research assistance.

1. See generally Laurence R. Tancredi \& Jeremiah A. Barondess, The Problem of Defensive Medicine, 200 Science 879 (1978). Skeptics about this view, of which I am one, maintain that the uncontrolled fee-for-service reimbursement system is at least equally to blame for defensive medicine, since its financial incentives dictate that defensive concerns are expressed in the form of more aggressive treatment (rather than, for instance, more time spent with the patient or more physician training-defensive responses that entail no greater reimbursement). See Frank A. Sloan \& Randall R. Bovbjerg, Medical Malpractice: Crises, Response, and Effects, Health Ins Ass'n Am Res Bull 1, 11 (May 1989) ("legal rules and process contribute to but alone are not sufficient causes of the malpractice crisis"). But this skeptical view also concedes that the two phenomena of health care spending and defensive medicine are related, only in a reverse causal order than first stated.

2. As summarized in Mark A. Hall, The Malpractice Standard Under Health Care Cost Containment, 17 L Med \& Health Care 347 (1989), this view also has its critics (again, I am one), who argue that malpractice law is perfectly capable of evolving to fit the changes produced by cost containment incentives because it sets the standard of care for physicians according to the customary practices that prevail in the profession. However, even such skeptics concede that, for this evolutionary adjustment to take place, some physicians must first expose themselves to potential liability by standing apart from the prevailing custom. Physicians may be reluctant to do so based on their 
Given the perceived relationship between the spending and malpractice crises, it would be serendipitous if a single intervention could be devised to address both of these crises-one stone for two birds. The use of costsensitive medical practice policies (referred to variously as standards, guidelines, and parameters) ${ }^{3}$ to determine the necessity and propriety of physician services offers just such a powerful agent for reform. If physicians could be induced to standardize medical practice to a greater degree, payers would be better positioned to determine which treatments are worth reimbursing, and doctors would be better able to determine which cutbacks will produce the least harm. ${ }^{4}$ Simultaneously, authoritative practice policies might make malpractice exposure more rational and predictable if the judicial system could be given precise and definitive pronouncements of the governing standards of care. If the same standards that determined payment also determined liability, doctors would no longer be forced to practice any more defensively than reimbursement systems supported, and malpractice law would not stand in the way of cost containment. Individual physicians, in particular, would not be forced to risk liability at the vanguard of a gradual (or abrupt) change in medical custom, since the adoption of a practice policy itself would automatically define the new legal standard of care.

perception that the judicial system is unfair. Id at 349-51. Therefore, it is critical to resolve the perceived tension between cost containment and malpractice reform, even if the perception is erroneous.

3. There is no consensus yet on the appropriate terminology. As one authoritative source put it:

There are several terms used to describe practice guidelines and review criteria developed from them. "Boundary guidelines" and "practice parameters" specify the limits of acceptable practice, and are easily adapted for use as criteria for utilization and quality review. "Pathway guidelines" provide recommendations for the best or preferred practice [but] are neither designed nor well suited for review. ... Some refer to formally developed practice guidelines as "clinical standards." We use the term "guidelines" to note that recommendations for proper clinical care embody varying degrees of uncertainty. Those in which there is great confidence could be offered as standards to which all should hold, but most should remain as guidelines until their validity as predictors of patient outcomes has been established. ... It is [also] useful to distinguish two kinds of practice guidelines. The first focuses on a particular procedure, such as coronary artery bypass surgery, and provides recommendations for how to use it. The second focuses on a particular patient problem, such as chest pain, and provides recommendations for appropriate care for a patient with a problem, including which service to provide.

Physician Payment Review Comm'n, 1989 Annual Report To Congress 220 n1, 226 n14 ("PPRC, 1989 Annual Report"). Following the lead of David Eddy, I use "practice policies" to refer generically to all of these characterizations and to avoid the loaded nature of some of these terms. David Eddy, Practice Policies-What are They?, 263 J Am Med Ass'n 877, 878 (February 9, 1990). See Harris Meyer, Medicine Debates Parameters (or are They Guidelines?), Am Med News 36 (December 15, 1989) ("People are using loose terms to cover sharp disagreements. The AMA has chosen 'parameters' rather than 'standards' because, Dr. [James] Todd [executive vice-president of the AMA] said, a parameter builds a fence around a subject with a lot of room inside to allow for variations in patients, resources, and diseases." ").

4. The experience in England under the National Health Service suggests that doctors become more effective cost-cutters when resource constraints are incorporated into the doctor's conception of the governing standard of care than when they are asked to depart from the standard of care to accommodate cost constraints. See generally Henry Aaron \& William Schwartz, The Painful Prescription: Rationing Hospital Care (Brookings Institution, 1984). 
Unfortunately, the matter is not this simple. A practice policy will lose its definitive effect unless it is sufficiently mandatory and concrete to operate almost as a clinical protocol. Otherwise, ambiguities and questions of interpretation will exist that require fact-intensive litigation. The fact that few rigid standards exist ${ }^{5}$ means that the defensive effect of practice policies requires more careful examination.

This article explores the theoretical prospects for medical practice policies to reform malpractice law by giving conclusive defensive effect to medical custom. ${ }^{6}$ Part II first describes the groundswell of enthusiasm for practice policies. Part III then examines the potential of practice policies to address flaws in the malpractice system, and, finally, Part IV responds to objections to giving practice policies conclusive defensive weight in litigation.

\section{II}

\section{The Movement for Medical Practice Policies}

Practice policies have long been commonplace in the form of textbooks, journal articles, and "conversations in hospital cafeterias." 7 However, they are now "being designed explicitly as instruments for quality assurance ... and cost containment" 8 in a much more organized fashion. The American Medical News, the official newspaper of the American Medical Association ("AMA"), devoted most of its 1988 year-in-review issue to this topic. The issue detailed the coordinated efforts of the AMA, medical specialty societies, private research groups, and the government to bring greater standardization to medical treatment. ${ }^{9}$ These developments stand in stark contrast to

5. Eddy categorizes practice policies into three groups according to their degree of prescriptiveness: (1) standards, which apply rigidly; (2) guidelines, which are more flexible; and (3) options, which are merely descriptive (that is, they make no recommendation at all). David Eddy, Designing a Practice Policy: Standards, Guidelines and Options, $263 \mathrm{~J}$ Am Med Ass'n 3077 (June 13, 1990). He argues that, given the present lack of information about clinical outcomes and patient preferences, there will be few standards and many options. Id at 3083-84.

6. In focusing on the defensive effect of practice policies, I depart from other commentators by excluding any concern over the offensive use of these policies. Compare Am Med Ass'n, Legal Implications of Practice Parameters (Am Med Ass'n, 1990) (primary focus on whether practice policies will increase legal exposure) ("AMA Report"); Eleanor D. Kinney \& Marilyn M. Wilder, Medical Standard Setting in the Current Malpractice Environment: Problems and Possibilities, 22 UC Davis L Rev 421 (1989) (same). I believe the material inquiry should be whether practice policies are capable of protecting compliant doctors from liability, not whether such policies might increase the liability exposure for those doctors who violate them. As a generalization, cost containment is achieved by doing less, rather than more. Therefore, the assumption with cost-sensitive practice policies is that they will generally lower the standard of care. or, perhaps more accurately, that they will move the standard of care toward the lower end of the broad range of existing practice patterns. While crystallizing practice standards will also make it easier for injured patients to establish negligence, it is not a legitimate public policy objection that liability will result for those doctors that fall below a less demanding standard of care than currently exists. Increased risk of such liability is not likely to offset the benefit of the overall decreased risk that may accompany the defensive use of standards, provided the standards themselves clarify precisely what the law requires.

7. David M. Eddy, Practice Policies: Where do They Come From?, 263 J Am Med Ass'n 1265, 1265 (March 2, 1990).

8. Eddy, $263 \mathrm{~J} \mathrm{Am} \mathrm{Med} \mathrm{Ass'n} \mathrm{at} 880$ (cited in note 3).

9. See generally Am Med News (January 6, 1989). 
organized medicine's traditional opposition to any sort of formal standardsetting. ${ }^{10}$

\section{A. Government-Sponsored Practice Policies}

The most prominent manifestation of the movement is Congress's establishment of practice policy development as a major priority. " legislation created the Agency for Health Care Policy and Research within the Public Health Service to "arrange for the development and periodic review and updating of clinically relevant guidelines, . . . standards of quality, performance measures, and medical review criteria."12 These practice policies must "include treatment-specific or condition-specific practice guidelines for clinical treatments and conditions in forms appropriate for use in clinical practice . . . and for use in reviewing quality and appropriatengss of medical care."13

The same legislation fundamentally changes how Medicare pays doctors, in a manner that will increase doctors' incentive to create more cost-sensitive practice policies. Beginning in 1992, Medicare will use a legislated fee

10. An illustrative expression of the traditional view is found in the editorial pages of American Medical News only three weeks before it published its 1988 year-in-review, see id:

To be quite candid, I have no idea what the standard of care really is, and my point is that neither does anyone else. . . . The medical community has no obligation to accept this concept. [Doctors and medical organizations should] reject the term and concept of "standard of care." In fact, there is no standard of care. The medical body of knowledge contains both fact and opinion. Each case must be assessed on individual merits, including intangible factors and only from the prospective viewpoint.

Robert P. Nirschl, Delving Into Myth of "Standard of Care, "Am Med News 24, 26 col 2 (December 16, 1988).

11. Omnibus Budget Reconciliation Act of $1989 \S 6103$, Pub L No 101-239, 103 Stat 2106, 2189-2209, 42 USC $\S 299$ ("Budget Reconciliation Act"). The practice policy movement is also strongly endorsed by the Physician Payment Review Commission ("PPRC"). PPRC, 1989 Annual Report (cited in note 3); PPRC, 1990 Annual Report to Congress 235 ("1990 Annual Report").

Prior to this congressional action, the National Institutes of Health ("NIH") conducted over sixty consensus conferences on biomedical issues during the past decade, producing recommendations on a variety of techniques, devices, and drugs. The NIH convenes panels of recognized experts for several day sessions to review scientific findings and hammer out the areas of consensus and disagreement. Paul M. Wortman, Amiram Vinokur \& Lee Sechrest, Do Consensus Conferences Work? A Process Evaluation of the NIH Consensus Development Program, 13 J Health Pol, Pol'y \& L 469 (1988); Jacqueline Kosecoff, et al, Effects of the National Institutes of Health Consensus Development Program on Physician Practice, $258 \mathrm{~J}$ Am Med Ass'n 2708 (November 20, 1987); Seymour Perry \& John T. Kalberer, The NIH Consensus-Development Program and the Assessment of Health-Care Technologies: The First Two Years, 303 New Eng J Med 169 (1980); Kinney \& Wilder, 22 UC Davis L Rev at 432 (cited in note 6). Also, the Institute of Medicine at the National Academy of Sciences has, under congressional authorization, studied appropriate mechanisms for technology assessment. Institute of Medicine; Assessing Medical Technologies (Nat'l Acad Press, 1985). The Institute is presently advising the new Agency for Health Care Policy and Research.

12. Budget Reconciliation Act, 42 USC $\$ 299 \mathrm{~b}-1$ (a) (cited in note II).

13. Id at $\S 299 \mathrm{~b}-1(\mathrm{~b})(3)$. The statute continues with great detail. specifying the particulars of this undertaking in more than five pages of session laws and more than fifty subsections. The agency was required to develop at least three practice policies by the end of this year, and the statute specifies appropriations to start at $\$ 50$ million, increasing to $\$ 185$ million by 1994 . Id at $\$ 299 \mathrm{~b}-3$ (i). The Health Care Financing Administration ("HCFA"), which runs Medicare and Medicaid, will support this effort by using its Medicare and Medicaid data bases to assist in developing the hard information about patient outcomes from various procedures that is critical to formulating accurate practice policies. Kinney \& Wilder, 22 UC Davis L Rev at 433-34 (cited in note 6). 
schedule based on a "resource-based, relative value scale" that equalizes payment for various services according to a comparison of the time, intensity, and expense involved. ${ }^{14}$ This is a dramatic change from the prior system, which was based on customary and prevailing fees. An even more revolutionary change, however, is the pivotal step this legislation takes toward controlling the volume of physician services through an annual "volume performance standard." The volume standard sets a benchmark that Congress is to consider in determining the yearly update in the "conversion factor" that is used to translate relative value scores ${ }^{15}$ into actual dollar reimbursements. ${ }^{16}$ Such a mechanism allows Congress to lower the fee schedule (relative to inflation) to adjust for any increase in the total volume of services. The threat that all physicians might have to pay for the excesses of some is expected to give the medical profession "a collective incentive to foster approaches to cost containment, . . . includ[ing] developing and disseminating practice guidelines." 17

\section{B. Practice Policies Developed by Private Research and Payer Groups}

The most notable effort to date by a private research group is that headed by Dr. Robert Brook at RAND. RAND and the University of California at Los Angeles School of Medicine and Public Health have conducted a "health services utilization study" that assesses the appropriateness of care for a number of common procedures. ${ }^{18}$ The criteria used by the project's physician reviewers to judge appropriateness are generated by expert panels that consider summaries of the literature to derive a consensus on the

14. Budget Reconciliation Act, 42 USC \& 1395 w-4 (cited in note 11).

15. Relative value scores are the rankings used to equilibrate among various physician services to indicate their comparative worth in terms of time, effort, skill, and cost. See generally William Hsao, et al, The Resource-Based Relative Value Scale: Toward the Development of an Alternative Payment System, $258 \mathrm{~J}$ Am Med Ass'n 799 (August 14, 1987).

16. Budget Reconciliation Act, 103 Stat $2179-81$ (cited in note 11). Congress will set the volume performance standard ("VPS") according to the joint recommendations of the PPRC and the Secretary of the Department of Hcalth and Human Services ("HHS"), based on their consideration of factors such as medical inflation and unnecessary utilization. If Congress fails to act, a default provision will set the VPS at $2 \%$ below the old level, adjusted by an index of medical economic inflation. In setting the following year's update of the conversion factor, Congress will consider any differential in the present year between aggregate program expenditures and the VPS. If Congress fails to act, the conversion factor will automatically be adjusted for the exact percentage differential, either raising or lowering the following year's fee schedules to make up the difference. However, for the first five vears, there is a $2 \%$ to $3 \%$ Hoor on how much this default correction can drop. See Paul B. Ginsburg, Lauren B. LeRoy \& Glenn T. Hammons, Medicare Physician Payment Reform, 9 Health Aff 178 (Spring 1990).

17. PPRC, 1990.Annual Report at 27 (cited in note 11). If this doesn't work, the HHS Inspector General's Office will prod doctors along. It is shifting its investigation of Medicare/Medicaid fraud and abuse from payment arrangements to overutilization by using medical specialty society guidelines to screen physicians for investigation. Sharon Mcllrath, IG Shifting Focus to Ltilization, Am Med News 1 col 2 (January 26, 1990).

18. Robert H. Brook. Practice Cinidelines and Practicing Medicine: Are They Compatible?, $262 \mathrm{~J}$ Am Med Ass'n 3027, 3029 (December 1. 1989): Rolla E. Park. et al, Physirian Ratings of tppropriateness Indications for Six .Mediral and Surgical Procedures. 76 Am J Pub Health 766 (1986): Kinney \& Wilder, 22 UC Davis L. Rev at 426 nl9 (cited in note 6) (collecting citations to published results of the RAND appropriateness study). 
appropriateness of various indicators for the procedure in question. Panel members rate numerous possible medical indicators for a procedure on an appropriateness scale of one to nine. The tabulations are used to group the indicators into three categories-appropriate, inappropriate, and equivocal. ${ }^{19}$ RAND is presently expanding this effort by organizing a consortium with several academic medical centers and the AMA to develop and disseminate appropriateness indication ratings for twelve additional procedures. ${ }^{20}$ Eventually, Dr. Brook sees RAND developing appropriateness guidelines for 50 to 100 of the most common, expensive, and controversial procedures. ${ }^{21}$

There are numerous other private efforts at setting medical practice policies. The Blue Cross/Blue Shield Association commissioned the American College of Physicians ("ACP") to produce guidelines for the appropriateness of the fifteen most common diagnostic tests. ${ }^{22}$ For example, routine chest $\mathrm{x}$-rays upon hospital admission before surgery are considered unnecessary "unless the medical history or symptoms and signs of chest disease in the judgment of the physician" call for one. ${ }^{23}$ Although Blue Cross is not yet using these guidelines in conducting claims review, other insurers are. ${ }^{24}$ Other private consulting companies similarly supply hospitals, Health Maintenance Organizations ("HMOs"), and Preferred Provider Organizations ("PPOs") with programmed instructions for use in utilization review, quality assurance, preadmission certification, or concurrent review. ${ }^{25}$ Also, major voluntary health organizations, such as the American Heart Association, the American Cancer Society, and the American Diabetes Association, have developed practice policies in collaboration with medical specialty societies. ${ }^{26}$

19. For example, in the case of a coronary angiography (an invasive diagnostic test for heart disease, usually preliminary to cardiac surgery), one "appropriate" indicator used by RAND was "patient hospitalized for unstable angina"; an "equivocal" indicator was "patient has chronic stable angina (class III of IV), has received less then maximal medical therapy, and has undergone no exercise test"; and an "inappropriate" indicator was "patient's only cardiac abnormality is congestive heart failure." Mark R. Chassin, et al, Does Inappropriate Use Explain Geographic Variations in the Use of Health Care Services?, 258 J Am Med Ass'n 2533, 2535-36, Tables 4, 5 \& 6 (November 13, 1987).

20. Harris Meyer, $A M A$, Rand [and] Academic Centers to Develop Practice Guides, Am Med News 3 col 1 (April 6, 1990) (coronary artery bypass, carotid endarterectomy, aortic aneurism surgery, cataract surgery, coronary angioplasty, abdominal ultrasound, cholecystectomy, lower extremity bypass graft, electrocardiography, hip replacement, prostatectomy, and laminectomy).

21. Meyer, Am Med News at 36 col 1 (cited in note 3).

22. See Philip R. Alper, ACP Guidelines for Common Diagnostic Tests and the Practicing Internist, $4 \mathrm{~J}$ Geil Intern Med 548 (1989); David Tennenbaum, Blue Cross/Blue Shield Association's Perspective on the Common Diagnostic Test Guidelines, $4 \mathrm{~J}$ Gen Intern Med 553 (1989); Kinney \& Wilder, UC Davis I. Rev at 424 (cited in note 6). The ACP's recommendations are based solely on its staff's review of the existing medical literature.

Aetna and Blue Cross/Blue Shield are also using a computer system developed by RAND to evaluate appropriateness. Harris Meyer, Payers Reluctant to Tread Standards Water. Am Med News 20 col 1 (January 6, 1989).

23. Blue Cross/Blue Shield Association, Press Release (April 2, 1987).

24. Physicians Wary of HCFA's Proposed Medical Standards, Hospitals 24, 25 (May 5, 1988)

25. Kinney \& Wilder, 22 UC Davis L Rev at 437 (cited in note 6); Paul M. Gertman \& Joseph D. Restuccia, The Appropriateness Evaluation Protocol: A Technique for Assessing Unnecessary Days of Hospital Care, 19 Med Care 855 (1981)

26. Kinney \& Wilder, 22 UC Davis L Rev at 430-31 (cited in note 6). Medical practice policies are also being developed to meet institution-specific purposes at numerous hospitals and HMOs. See Mark A. Hall, Institutional Control of Physician Behavior: Legal Barriers to Health Care Cost Containment, 


\section{Practice Policies Developed by the Medical Profession}

The AMA has undertaken a "parameters project" to coordinate the activities of various specialty societies. It also has recently agreed to combine forces with the RAND consortium by taking RAND's appropriateness criteria and turning them into more "user-friendly" guidelines that give specific directions in particular clinical situations. ${ }^{27}$ A cynic might charge that the AMA's efforts are designed only to accept the inevitable by pre-empting outsiders from forcing even more threatening practice policies on the profession. Indeed, the AMA is explicit in its desire to keep practice policies flexible and open-ended and to exclude all considerations of cost. ${ }^{28}$ Nevertheless, the work of a number of individual specialty societies is beyond reproach.

The pioneer has been the American Society of Anesthesiologists. Their latest effort is a 1986 set of standards for monitoring patients under anesthesia, ${ }^{29}$ including standards such as: "Every patient receiving anesthesia shall have arterial blood pressure and heart rate determined and evaluated at least every five minutes." "30 Other models include the task force formed by the American College of Cardiology and the American Health Association to recommend appropriate use of technology in the diagnosis and treatment of heart disease, ${ }^{31}$ and the set of clinical indicators for fifteen common Ob/Gyn procedures recently completed by the American College of Obstetricians and Gynecologists. ${ }^{32}$ The AMA has collected over 1,100 existing practice

$137 \mathrm{U}$ Pa L. Rev 431, 450 (1988) ("Health care institutions are now issuing 'rigid protocols or standards of care' with increasing frequency, covering a broader range of activity, often as binding directives."). A leading example is the "Standards for Patient Monitoring During Anesthesia" established at Harvard Medical School. John Eichorn, et al, Standards for Patient Monitoring During Anesthesia at Harvard Medical School, $256 \mathrm{~J}$ Am Med Ass'n 1017 (August 22, 1986); Kinney \& Wilder, 22 UC Davis L Rev at 435 (cited in note 6). Also, New York City pediatric clinics have implemented a computerized treatment protocol system that establishes mandatory "uniform diagnosis and treatment procedures . . . for 85\% of pediatric illnesses." Ronald Sullivan, City Expanding Use of Computers to Monitor Pediatric Care, NY Times B24 col 1 (February 29, 1984).

27. Meyer, Am Med News at 3 col 1 (cited in note 20). See Kinney \& Wilder, 22 UC Davis L Rev at 423, 427 (cited in note 6) (AMA endorsement of clinical practice parameter development); $A M A$ Report at 1 (cited in note 6 ).

28. Ronni Scheier, Medicine by the Book, Am Med News 1 col 1 (January 6. 1989) ("The AMA acted aggressively to make certain the profession-not government or other payers-would write those guidelines."); id at $14 \mathrm{col} 5$ ("What we have to avoid," said Dr. Todd, [executive vice president of the AMA,l "is developing parameters based on economic considerations. . . . Effectiveness. appropriateness, necessity-to the government those are euphemisms for cost control and rationing."): Interilew with James S. Todd, AMA Exec. V.P., Am Med News 15 col 1 (January 6, 1989) ("You cannot restrict physicians to one procedure or series of procedures for a specific condition. No two patients are exactly alike and no two conditions are exactly alike.").

29. Scheier, Am Med New's at 14 (cited in note 28).

30. Am Soc'y Anesthesiologists ("ASA"), Standards for Basic Intra-Operative Monitoring (ASA, 1986).

31. Special Report: Guidelines for Coronary Angiography, $10 \mathrm{~J}$ Am College Cardiology 935 (1987) ("Coronary Angiography Guidelines"). Notes 60-62 contain a partial description of these guidelines.

32. 63 Hospitals 52 col 1 (August 20, 1989). For instance, they recommend a Pap smear every three years after a series of negative one-year exams. Robin Marantz Henig, Is The Pap Test Valid?, NY Times 37 col 1 (May 28, 1989). 
policies, ${ }^{33}$ and fifteen of the twenty-four specialty societies are actively developing practice policies, with the rest likely to follow suit. ${ }^{34}$

These developments are generating great enthusiasm over the prospect that practice policies may improve the quality and reduce the cost of medical care. What deserves more emphasis is their potential for effecting legal reform by creating more rigorously defined standards of care that improve the functioning of the malpractice system. Specifically, physicians may miss the potential ability of medical practice policies to protect them from legal exposure because of their common misapprehension that everything associated with malpractice law is oppressive. The following analysis addresses this misperception. It demonstrates, first, that practice policies, if properly crafted, can have considerable defensive effect under existing law, and, second, that uncertainties regarding this potential defensive effect should be removed by legislation that carefully specifies the precise immunity practice policies should create.

\section{III}

\section{The Defensive Effect of Medical Practice Policies Under Existing LAW}

\section{A. Medical Custom and Malpractice Law: Theory and Practice}

In garden-variety tort cases, the jury is the ultimate arbiter of the appropriateness of the defendant's conduct when that conduct is within the common purview of lay persons. Evidence as to what is customary may be considered to inform the jury in its deliberations, but "courts must in the end say what is required; there are precautions so imperative that even their universal disregard will not excuse their omission."35 Medical malpractice cases depart sharply from these dictates. In this special category of cases, it is thought that the jury lacks sufficient expertise to evaluate independently the propriety of physicians' conduct. Therefore, jurors are instructed to judge physicians not by the jury's sense of what is right, but by the custom that prevails in the profession. ${ }^{36}$ In theory, then, malpractice law is distinctly more

33. Am Med Ass'n, Directory of Practice Parameters, Guidelines, and Technology Assessments (Am Med Ass'n, 1990).

34. Laurie Abraham, Specialties Race Against Payers to Set Standards, Am Med News 17 col 1 (January 6, 1989). Kinney \& Wilder, 22 UC Davis L Rev at 428-30 (cited in note 6), summarize work completed or underway by the American College of Physicians, the American Society of Internal Medicine, the American Academy of Pediatrics, the American College of Surgeons, the American College of Obstetrics and Gynecology, and the American Academy of Family Physicians.

35. The T.J. Hooper, 60 F2d 737, 740 (2d Cir 1932).

36. The seminal article is Allan H. McCoid, The Care Required of Medical Practitioners, 12 Vand L Rev 549, 605-09 (1959). As recent commentators put it, "the judge and jury have no role in evaluating the defendant physician's conduct directly but rather only evaluate the persuasiveness of the expert testimony in light of all other evidence." Kinney \& Wilder, 22 UC Davis L Rev at 440 (cited in note 6). The only exception to this rule is where the defendant's conduct is so clearly imprudent that the jury is capable of evaluating it based on lay information, such as when a surgeon leaves a sponge inside a patient. This exception remains rather rare in malpractice litigation. See Comment, Helling v. Carey: A Landmark or Exception in Medical Malpractice; Compliance with the Medical 
protective of physicians (and other professionals) than general tort law is of ordinary defendants. It "gives the medical profession ... the privilege, which is usually emphatically denied to other groups, of setting their own legal standards of conduct, merely by adopting their own practices." 37

However, the practical difficulties of proving just what is the prevailing medical custom break down this protective theory in the real world. Lacking any definitive pronouncements of custom, litigants must resort to the testimony of individual expert witnesses hired to evaluate the specifics of the case on an ad hoc basis; the opinions of the experts on each side are often in disagreement. When this happens, what in theory is supposed to be a process of comparing the defendant's conduct with established professional norms degenerates into a swearing contest. In this contest, in the view of many, when the plaintiff's witness states that the defendant's conduct was not within the standards of the profession, he really means only that he "would not have treated the patient that way." 38 The custom rule is intended to have the substantive effect of keeping from the jury the ultimate issue of reasonableness. Instead, it serves only to put in issue the credentials and the testimony of the witnesses who are enlisted to present the very issue of ultimate reasonableness to the jury.

The legal system is not entirely to blame for this state of affairs. To a large extent, it is created by the present state of medical science, which so thoroughly fails to conform to the legal ideal of an established standard of care. In most instances, no such definitive standard exists. Instead, there are vast differences in the frequency with which different groups of doctors employ many medical procedures. ${ }^{39}$ Practice patterns vary so greatly because

Standard of Care May Not Protect the Specialist from Liability, 11 New Eng L Rev 301, 308 (1975) (authored by Neil Meltzer).

37. W. Page Keeton, Prosser and Keeton on the Law of Torts 189 (West, 5th ed 1984).

38. This point is well put in a recent article: "Many physician [experts] rely on how they would have conducted themselves in the particular situation at issue. This is particularly true if there are no standards, recommendations or guidelines .... As a result, a defendant physician often is held to a standard of care that reflects the "habit' of the [plaintiff's] medical expert testifying." Kinney \& Wilder, 22 UC Davis L Rev at 441-42 (cited in note 6). See also Hospitals at 52. col 1 (August 20, 1989) (noting that "many standards of practice are set in the courtroom and that "[t]he expert witness has an opinion and a case is decided on that" ") (quoting C. Irving Meeker, M.D.. with the American College of Ob/Gyn's); Intervieu' with James $S$. Todd, Am Med New's at 15 col 5 (cited in note 28) ("Part of the reason physicians fare so poorly in court is because anybody can say the standard is anything he thinks it ought to be. If you put two experts in a courtroom, on opposite sides of the issue, who's the jury going to believe?").

While this analysis holds only in contested cases that go to the jury-a small percentage of all malpractice claims filed-the outcomes in these cases strongly influence how litigants and insurance companies behave in settlement negotiations.

39. Medical epidemiologists, through a technique known as "small area analysis," have documented variations among New England communities of sixfold in the rate of tonsillectomies and fourfold in the rate of hysterectomies. John Wennberg, Klim McPherson \& Philip Caper, Will Payment Based on Diagnosis-Related Groups Control Hospital Costs?. 311 New Eng J Med 295 (1984); John Wennberg \& Alan Gittelsohn, Variations in Mediral Care Among Small Areas. 246 Sci Am 120 (April 1982); John Wennberg \& Alan Gittelsohn, Small trea lariations in Health Care Delivery. 182 Science 1102 (1973). Equally large variations have been documented for other medical procedures, including a seventeenfold variation in test ordering within a single hospital. Studies are collected 
"[u]ncertainty pervades medical diagnosis and treatment."40 "Medical knowledge is engulfed and infiltrated by uncertainty"; 41 it "creeps into medical practice through every pore."42

Still, one would expect legal theory to make a more honest appraisal of this state of medical science. Ostensibly, the law does so through two doctrines. The "respectable minority" rule recognizes variation in medical practices. It declares that a doctor is not negligent merely by differing from some of his peers if he follows a course of conduct that has the support of a "school of practice" or a considerable number of practitioners in good standing. ${ }^{43}$ The "error in judgment" rule also recognizes medical uncertainty. It declares that, where two or more courses of treatment are legitimate, a doctor is not negligent for an error in choosing one of them. ${ }^{44}$ These two doctrines therefore offer a potentially powerful tool to limit the jury's scope of decision despite a conflict in the expert testimony over the propriety of care rendered.

Given the remarkable divergence of opinion on most questions of medical practice, one would expect the respectable minority and the error in judgment rules to be invoked frequently in a preclusive fashion in procedural motions such as those for summary judgment or directed verdict. In fact, these doctrines are usually used only in framing instructions to the jury. ${ }^{45}$ Litigants

and discussed in Pamela Paul-Shaheen, Jane Clark \& Daniel Williams, Small Area Analysis: A Review and Analysis of the North American Literature, $12 \mathrm{~J}$ Health Pol, Pol'y \& L 741 (1987).

40. Alain C. Enthoven, Health Plan xix (Addison-Wesley, 1980).

41. Jay Katz, The Silent World of Doctor and Patient 166 (The Free Press, 1984).

42. David M. Eddy, Variations in Physician Practice: The Role of Uncertainty, Health Aff 74, 75 (Summer 1984). See also Eric Fortess \& Marshall Kapp, Medical Uncertainty, Diagnostic Testing, and Legal Liability, 13 L Med \& Health Care 213 (1985); Renee Fox, The Evolution of Medical Uncertainty, 58 Milbank Mem Fund $Q 1$ (1980) (discussing the increase in the level of uncertainty brought about by modern scientific developments); John Wennberg, Benjamin Barnes \& Micheal Zubkoff, Professional Uncertainty and the Problem of Supplier-Induced Demand, 16 Soc Sci Med 811 (1982).

43. Joseph H. King, The Law of Medical Malpractice 66 (West, 2d ed 1986); David W. Louisell \& Harold Williams, 1 Medical Malpractice $\$ 8.04$ n27 (Mathew Bender, 1990).

44. King, The Law of Medical Malpractice at 69 (cited in note 43); Louisell \& Williams, 1 Medical Malpractice $\$ 8.04$ at $n 28$ (cited in note 43). Exemplary of those older opinions that used shades of both of these rules is McPeak $v$ Vanderbilt Univ. Hosp., 229 SW2d 150 (Tenn App 1950), in which the court reasoned:

Physicians and surgeons must be allowed a wide range in the exercise of their judgment and discretion. The science of medicine is not an exact science. In many instances there can be no fixed rule by which to determine the duty of a physician, but he must often use his own best judgment and act accordingly. By reason of that fact the law will not hold a physician guilty of negligence . . . even though his judgment may prove erroneous in a given case, unless it be shown that the course pursued was clearly against the course recognized as correct by the profession generally. As long as there is room for an honest difference of opinion among competent physicians, ... a physician will not be held liable for malpractice if he follows the course of treatment advocated by a considerable number of physicians of good standing in the community. It would not be competent for a court or jury in such a case to say that a physician who followed either of said different methods of treatment was negligent.

Id at 152 (quoting Bailey y St. Louis-San Francisco R. Co., 296 SW 477, 479 (Mo App 1922)).

45. King. The Law of Medical Malpractice at 70 (cited in note 43) ("As a practical matter, the "error in judgment' rule rarely is automatically outcome determinative of a case. Generally, it is simply included in the instructions to the jury."); Louisell \& Williams. 1 Medical Malpractice $\$ 8.04$ at n27 (cited in note 43) ("whether the minority's practice is truly 'respectable' or 'reputable' is of course a 
have learned that the pre-emptive effect of these rules is easily avoided by eliciting from their physician witnesses not merely a difference of opinion as to the proper course of treatment, but an expression that the opposing opinion is illegitimate. ${ }^{46}$ Thus, it is usually a simple matter to create a factual dispute over the respectability of an alternative practice, if not its existence, leaving the jury to decide which of two opposing treatment methods is correct. ${ }^{47}$ This breakdown between theory and practice essentially allows the jury to impose, based on its own independent judgment, the governing standard of care-the very result malpractice law attempts to avoid.

\section{B. The Effect of Practice Policies in Theory and in Practice}

Practice policies offer a potentially powerful mechanism for rehabilitating the role of custom in defending against malpractice charges. The breakdown between the theory that the law applies a rule of professional custom and the practice of many malpractice trials occurs for the very reason that the law has

proper subject for expert evidence"). For a sampling of recent cases, see Davis $v$ Coastal Emergency Services Inc., 868 F2d 1223 (11th Cir 1989); Trent v Trotman, 352 Pa Super 490, 508 A2d 580 (1986); Borja y Phoenix General Hosp., 151 Ariz 302, 727 P2d 355 (Ariz App 1986); Estate of Smith v Lerner, 387 NW2d 576 (Iowa 1986); Laughridge v Moss, 163 Ga App 427, 294 SE2d 672 (1982); Joy v Chau, 177 Ind App 29, 377 NE2d 670 (1978); Pettis v Louisiana, 336 So2d 521 (La 1976).

The following two decisions are notable exceptions: Goldstein $v$ Kantor, 101 Ill App3d 264, 268, 427 NE2d 1322, 1325 (1981) ("We do not regard [the expert witnesses'] difference of opinion, if it existed, as evidence of an issue as to the medical malpractice of the defendant. The possibility of a different treatment from the one performed does not per se raise a question as to the defendant's professional competence ...."); Chumbler v McClure, 505 F2d 489 (6th Cir 1974), in which the court noted:

The most favorable interpretation that may be placed on the testimony adduced at trial below is that there is a division of opinion in the medical profession regarding the [treatment in question] and that Dr. McClure was not alone among neurosurgeons in Nashville in using such therapy. ... [This] leave[s] no other possible outcome other than plaintiff's failure to present even a prima facie case of malpractice.

Id at 492-93.

46. For example, in Furey $v$ Thomas Jefferson University Hospital, 325 Pa Super 212, 472 A2d 1083 (1984), the court invoked the respectable minority rule only to remand the case for retrial under proper instructions, and distinguished a previous decision that had reversed outright a jury verdict for the plaintiff. The court observed that, in the prior case,

the standing and ability of each of the experts was not questioned and so [a] jury may not decide which of two respected methods of treatment is the better one . . . Here, however, an initial jury question was presented as to whether or not there were two competent medical viewpoints on the treatment of severe bacterial infections. The defense strenuously attacked the credentials and expertise of Dr. Bass and both sides claimed that it would be malpractice to follow the treatment advocated by the other side. Faced with this testimony[,] . . we reverse and remand for a new trial.

Id at $225-26,228,472 \mathrm{~A} 2 \mathrm{~d}$ at $1090-91$.

47. Likewise, the error in judgment rule does not "support the view that once a medical decision somehow becomes judgmental, it is no longer subject to judicial scrutiny regardless of the quality of that judgment .... . [I]t is only non-negligent errors in judgment that will not result in liability." King, The Law of Medical Malpractice at 71 (cited in note 43). Therefore, the case must always go to the jury if the plaintiff's witness creates a dispute on the ultimate question of the propriety of the defendant's exercise of his judgment.

Moreover, these rules do not apply to a dispute over whether the chosen course of treatment was properly and carefully executed. See Morganstein "House. 377 Pa Super 512, 547 A2d 1180 (1988) (discussing limitations on the doctrine's applicability). Such disputes may characterize a large number of malpractice actions. See Lucian L. Leape, el al, The Nature of Adverse Events in Hospilalized Patients. 324 New Eng J Med 377 (1991). 
always presumed the existence of that which does not exist-established, concrete professional standards. Because the law has operated in an unreal twilight zone that assumes professional consensus when in fact much of medical practice is governed by instinct and localized habit, ${ }^{48}$ malpractice suits have tended to degenerate into individual skirmishes between opposing experts. Malpractice law can be vastly improved, then, by greater rationalization and standardization of medical practice. ${ }^{49}$

Practice policies would help to close the gap between theory and practice by using authoritative statements of existing practice to remove the factual uncertainty that presently surrounds the determination of whether some given practices are respectable. ${ }^{50}$ The legal standard claims to be guided solely by the standard recognized in the profession; thus, in theory, if the same entity that determines professional status also declares the professional practice, its declaration, by definition, would be controlling. This is especially true for consensus statements by medical societies widely representative of the entire profession. However, even if the promulgating organization represents only a minority segment of the profession, as long as it is a "respectable" minority, under the theory mentioned above that malpractice law recognizes the possibility of several established customs, it should have conclusive defensive force for doctors who comply.

Practice policies might be thought to lose their conclusive effect if the promulgating entity is not an organ of the profession itself. As summarized at the outset, much standard-setting activity is being undertaken by government, by academic and private research institutions, and by private insurance companies. ${ }^{51}$ However, practice policies need not be developed by the profession itself to receive professional imprimatur. If independent organizations in their process of standards development consult with professionals who represent recognized segments of the medical profession, and if these organizations base their standards on professional literature, the product should still be considered a conclusive statement of a standard of care that exists in the profession. ${ }^{52}$

48. See John M. Eisenberg, Doctors' Decisions and the Cost of Medical Care 103 (Health Admin Press Perspectives, 1986) (noting that physicians rely heavily on a clinical instinct that is acquired during the professional socialization process); Eliot Freidson, Professional Dominance 182-83 (Atherton Press. 1970) ("Much of what is called patient management . . . is not sustained or chosen by any systematic scientific knowledge, but rather by personal preference and experience and by occupational custom and folklore."); Hall, $137 \mathrm{U} \mathrm{Pa} \mathrm{L} \mathrm{Rev} \mathrm{at} \mathrm{480-83} \mathrm{(cited} \mathrm{in} \mathrm{note} \mathrm{26).}$

49. See Scheier, Am Med News at $14 \mathrm{col} 3$ (cited in note 28) (anesthesiologists in Oregon and Massachusetts receive discounts of $15 \%$ and $20 \%$ in malpractice premiums for adhering to guidelines).

50. See Mark Chassin. Standards of Care in Medirine. 25 Inquiry 437, 448 (1988):

Currently, the legal process faces far more difficulty in uncovering what the standard of care is in a particular domain of medicine than it does in adjudicating matters of fact regarding what actually took place in a particular case. How much simpler it would be if there existed a set of standards about which there could be little debate. The focus of the legal process would then be on whether there were any extenuating circumstances mitigating the application of the standard in the particular case.

51. See notes 11-26 and accompanying text.

52. For further discussion, see notes 94-97 and accompanying text. 
However, this is stated as a matter of theory, and, again, there is a gap between theory and practice. A search of the case law reveals that courts generally give professional standards only the limited effect of admission into evidence, not determinative weight as to the standard of care. ${ }^{53}$ Although some might speculate that juries will give expert testimony for the defense greater weight when it is backed up by statements of authoritative medical groups, this is an undetermined matter for empirical verification; in any event, it is of little consolation to doctors who will still fear facing juries they perceive to be incompetent. ${ }^{54}$ It would be preferable to give authoritative practice policies pre-emptive effect that precludes opposing testimony about the applicable standard of care. It is not clear why the law presently does not recognize this conclusive effect, but several possibilities suggest themselves.

1. Distinguishing Offensive and Defensive Precedents. First, all of the existing precedents for the inconclusive effect of practice policies deal with their offensive use by plaintiffs. ${ }^{55}$ These cases are restricted to the conventional question of whether a plaintiff may rely on formal standards to establish a prima facie case against physicians who violate them and whether the defendant may justify a deviation from the standards. ${ }^{56}$ These precedents do not determine whether formal standards are given conclusive effect in a defensive posture when invoked by physicians who comply with them. This difference in the posture of the precedents is critical because of the possibility that two schools of practice might prevail. With this possibility in mind, it makes eminent sense to hold that it is not conclusive for a plaintiff to establish that the defendant violated one established standard. However, the opposite holds for a defendant who complies with at least one established professional guideline: because it is not necessary for a doctor to show that unanimous professional consensus supports his conduct, a defense is sufficiently established if the doctor shows only that she complied with at least one respectable body of opinion. Therefore, the existing precedents are not on point.

2. Complications of Proof. A second possible reason that existing law may fail to give conclusive defensive effect to professional standards is that the rules of

53. See Rodriquez y Jackson, 118 Ariz 13, 574 P2d 481 (1977): Bradford ‘ McGee, 534 So2d 1076 (Ala 1988): James "Woolley, 523 So2d 110 (Ala 1988); Pollard $:$ Goldsmith, 117 Ariz 363, 572 P2d 1201 (1977). For instance. in Darling : Charleston Community 1/em. Hosp. 33 Ill2d 326. 211 NE2d 253, 257 (1965), the court held: "The regulations, standards, and bylaws which the plaintiff introduced into evidence, performed much the same function as did evidence of custom. This evidence aided the jury in deciding what was feasible and what the defendant knew or should have known. It did not conclusively determine the standard of care

54. To further explore this empirical dimension of the behavior of various actors under malpractice law, see Thomas B. Metzloff. Researching Litigation: The Medical Malpractice Example, 51 L \& Contemp Probs 199 (Autumn 1988).

55. See note 53.

56. Similarly, Dornette focuses solely on whether plaintiffs may invoke standards that defendants voluntarily adopt. William Dornette. The Legal Impact on Voluntary Standards in Cizil Actions Against the Heallh Care Provider. 22 NY' L Sch L. Rev 925 (1977). 
evidence may prevent most cases from presenting such a clearly focused issue. Defense attorneys are not permitted to introduce formal practice policies into evidence by, for example, simply handing a copy of them to the judge or jury. Documentary evidence offered to prove the truth of the document's contents (as opposed to the mere existence of the document) 'technically constitutes hearsay. Exceptions to the exclusion of hearsay are available, but to fall within them it is necessary for a live witness to establish a foundation (where the document came from, who wrote it, for what purpose). In medical cases, this usually takes the form of the expert witness citing the document as supporting authority for the expert's opinion as to the professional practice. ${ }^{57}$ In such cases, the document is not introduced into evidence but is orally recited to the jury. These mechanics of proof tend to reduce the status of a formal practice policy from an official pronouncement of an authoritative professional group to merely the opinion of an individual doctor, no better than the opinion of the other expert, who may testify based on a different conception of proper medical practice. ${ }^{58}$

3. Vagueness and Uncertainty in the Standards. The third reason for a lack of precedential support for the protective effect of practice policies is that, until recently, the policies that existed were phrased in too vague and open-ended a manner to constitute a definitive statement of professional standards. ${ }^{59}$ To illustrate, a practice policy might be phrased in the following form for a diagnostic procedure: Procedure $\mathrm{A}$ is appropriate only if condition $\mathrm{X}, \mathrm{Y}$, or $\mathrm{Z}$ exists. ${ }^{60}$

Suppose a case where the doctor does not perform $\mathrm{A}$, harm results, and the doctor seeks protection under the standard. If the stated conditions are in the nature of "the patient has blood pressure above value $Q$ " determining the standard's applicability should be straightforward (unless, of course, there is a dispute over how the patient's blood pressure was taken). ${ }^{61}$ However, if the conditions $\mathrm{X}, \mathrm{Y}$, or $\mathrm{Z}$ state something like "relevant complications exist,"

57. See generally Kinney \& Wilder, 22 UC Davis L Rev at 442-46 (cited in note 6).

58. Id at 446 ("as a practical matter, the 'mechanics' of putting on proof of the standard of care in a malpractice lawsuit are fundamentally unaffected by the use of medical standards").

59. One medical journalist has reported:

Standards promulgated by specialty societies traditionally have not gone much beyond the Hippocratic oath: Do no harm; do what's best. . . The biggest problem with standards in the past, Dr. Gartland said, is that they have been too vague. "A lot of practitioners want [standards] to be so watered down that they're meaningless. . . The more specific [standards] are, the more our guys scream."

Abraham, Am Med News at 17 col 1 (cited in note 34) (quoting Dr. John Gartland of the American Academy of Orthopaedic Surgeons).

60. This form is suggested by the examples contained in PPRC, 1989 Annual Report at 226 (cited in note 3) ("It is appropriate to perform coronary angiography for a patient with nonspecific chest pain and a positive treadmill test, but inappropriate for a patient with [only] stable mild angina.") (summarizing Coronary Angiography Guidelines (cited in note 31)); and in Chassin, 25 Inquiry at 438 (cited in note 50) ("a patient with anemia should have a blood smear examined under the microscope").

61. See, for example, the Coronary Angiography Guidelines at 935-50 (cited in note 31) ("There is general agreement that coronary angiography is justified" for patients with a prior heart attack who produce certain numerical results in exercise ECG testing; "there is general agreement that [the 
the factual disputes over whether the standard applies will greatly multiply. ${ }^{62}$ Even more extreme, if the conditions indicate something like "the doctor has a hunch that procedure A might be helpful" (as the AMA essentially recommends that all policies state), ${ }^{63}$ the statement will lose any semblance of a guiding standard and the case will degenerate into a conventional battle of experts.

Precisely where practice policies lie on this continuum is a major determinant of the conclusiveness that courts can give them. The lack of support for giving them conclusive effect may be due, in large measure, then, to the absence of sufficiently definite standards. ${ }^{64}$

For these reasons, the present state of the law does not negate the proposition that definitive professional standards should be given conclusive defensive weight in malpractice litigation. The law simply has not yet had an opportunity to confront this issue directly. A better sense of what the law will do with this issue might be obtained from examining precedents in analogous areas of professional liability, such as accountant and attorney malpractice. ${ }^{65}$ Several courts have stated that accounting guidelines "without any doubt, fix[] the existing and accepted standards of the[] profession." 66 Other courts are less complaisant, however, refusing to consider whether an accountant's report "satisfies esoteric accounting norms, comprehensible only to the initiate." 67

procedure] is not ordinarily justified" for such patients with abnormal ECG testing results that do not fall within the specified "high risk" or medium risk ranges.).

62. See id at 967A ("There is general agreement that coronary angiography is justified" for angina "that has proved inadequately responsive to medical treatment," which means "that angina significantly interferes with a patient's occupation or ability to perform his or her usual activities"; but "there is general agreement that coronary angiography is not ordinarily justified" in the "presence of mild, clinically stable angina pectoris.").

63. See notes $108-09$ and accompanying text.

64. See Chassin, 25 Inquiry at 441 (cited in note 50) ("The statements of guidance to physicians, issuing from [the current] haphazard process, are often unusable... [S]uch statements are often couched in terms so vague that physicians cannot infer specific recommendations on the practical problems they face.").

65. Accounting precedents might be particularly insightful, since the accounting profession is guided by numerous "Generally Accepted Accounting Practices" ("GAAP") and "Generally Accepted Auditing Standards" ("GAAS"), issued by the American Institute of Certified Public Accountants.

66. Stanley I... Bloch, Inc. v Klein, 45 Misc 2d 1054, 258 NYS2d 501, 506 (1968) (offensive use of the standards). In the only article on point, the author concludes that "a CPA satisfies the duty of care required in auditing when he performs the audit in accordance with GAAS and . . GAAP." Willis Hagen, Certified Public fcromitants Liability for Malpractire: Effect of Compliance irith C.AAP and G.tAS. 13 J Contemp I. 65. 78 (1987). Hagen relies primarilv on Coss "Crossley. 567 F Supp 609, 617 (D Hawaii 1983) ("Generalls, an accountant or auditor discharges his professional obligations by

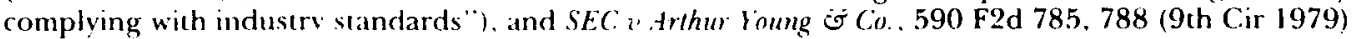
(holding "that (AAS required no more than /the defendant/ had done" and that "no more was required" by the federal securities law)

67. Herifeld "lanemthol, krakstem. Horuath is Horurath. 378 F Supp 112. 121 (SD NY 1974) (defensive use of the itandards). See also l'nited States "Simon. 425 F2d 796 (2d Cir 1969) (compliance with (BAP is 101 a conclusive defense to criminal fraud charges under the federal securities law).

For introductorv authorities on attornev malpractice under the Code of Professional Responsibility, see I'ondruff "Tomlim, 616 F2d 924,936 (6) Cir 1980) (noting that the Code "constitutes some evidence of the standards required of attorneys") (offensive use): Kirsch "Duryen, 
Thus, the most that can be said about the present state of the law is that it does not clearly reject the potential of professionally generated practice policies for addressing the medical malpractice crisis, but that, in its present form, it is far from embracing this potential. One means of resolving the uncertainty is legislative intervention to declare what effect practice policies should have in malpractice litigation. ${ }^{68}$

\section{IV}

\section{LEgislative Resolution}

\section{A. A Variable Immunity Statute}

The most obvious remedy for the uncertain legal response to the defensive potential of medical practice policies would be to legislate blanket tort immunity for physicians who comply with them. However, for a practice policy to be capable of conferring immunity simply on its face, it must be a precise and plain statement of the acceptable medical practice, and there must be no ambiguity regarding its application to the litigated case. In all probability, given the highly complex and variable nature of medical practice, such situations will be rare. Therefore, even if practice policies are accepted as conclusive statements in the abstract of the governing standard of care, significant questions of judgment and discretion will remain for the jury concerning whether the standard was complied with in a particular case.

These difficulties in fashioning blanket immunity suggest that an alternative legislative remedy should be considered, one capable of tailoring the defensive effect of practice policies to the circumstances of individual standards and specific cases. One approach, which is being implemented in Maine, is to leave the issue with the jury. Maine recently enacted a "medical liability demonstration project" that establishes medical specialty advisory committees in anesthesiology, emergency medicine, and obstetrics and gynecology. These committees are charged with developing by 1992 "practice parameters and risk management protocols" that "define appropriate clinical indications and methods of treatment ... designed to avoid malpractice claims and increase the defensibility of the malpractice

21 Cal3d 303, 578 P2d 935, 940 (1978) (finding attorney protected where his conduct was required by the Code of Professional Responsibility and reversing trial verdict against attorney): Charles Wolfram, The Code of Professional Responsibility as a Measure of Attorney Liability in Civil Litigation, $30 \mathrm{SC} \mathrm{L}$ Rev 281, 282-83 (1979) ("To date the Code has actually not served as a very important source of assistance to courts in private litigation. In part this is attributable to the lack of clarity in the Code itself.") (offensive use).

68. Even if the present state of the law were clearer, legislative intervention would be advisable since the critical determinant of public policy is how physicians and insurance companies perceive liability risks in real world settings, not what the law states in theory. Hall, $17 \mathrm{~L}$ Med \& Health Care 347 (cited in note 2). Thus, even if the law more clearly gave conclusive defensive effect to professional standards, this doctrinal reality would be a moot point unless it were brought home in a manner that convinced physicians to practice less defensively and insurance companies to lower their malpractice premiums. Legislative intervention will better publicize the safe harbor created by professional standards than would academic analysis of legal precedent. 
claims that are pursued."'69 Thereafter, any physician who elects in advance to participate in the project may introduce these parameters and protocols into evidence as an affirmative defense. ${ }^{70}$ However, this appears to provide only an additional piece of evidence for the jury to consider; nothing in the statute explicitly makes the parameters and protocols binding or conclusive. Even if this effect could be derived by inference, the statute does little or nothing to avoid sending unmeritorious cases to the jury altogether or to channel the jury's discretion in balancing the appropriateness of the defensive standard against the standard about which the plaintiff's expert will testify.

A better approach would be to authorize trial judges to consider, without the jury present, the defense's proffer of practice policies as conclusive statements of the applicable standard of care. Unconstrained by the technical rules of evidence, the judge could efficiently decide the authoritativeness of the issuing organization 71 and whether questions of fact exist about the policy's application to the pending case. As appropriate to the case, the judge could:

(1) direct a verdict for the defense (if the standard is authoritative and indisputably applicable);

(2) instruct the jury as to the governing standard of care and leave questions of application for its decision (where authoritativeness is established but factual questions remain); or

(3) try the case in a normal fashion with no special instructions (where authoritativeness is in doubt).

This proposal might be termed a "variable immunity statute."

\section{B. Objections to an Immunity Statute}

Despite its ardent support of medical practice policies, the PPRC opposes, at least for now, the adoption of any form of malpractice immunity for doctors who comply with them. In its 1990 Annual Report, the PPRC raises two formidable objections to legislative intervention: (1) a similar provision in the

69. Maine Rev Stats Ann $§ \S 2972,2973$ (1990 Supp).

70. Id at $\$ 2975$. Plaintiffs may not use these parameters and protocols to advance their case, but they may respond once the physician chooses to invoke them in defense. Id at $\$ \S 2975,2977$. The project will not proceed unless at least $50 \%$ of the licensed physicians in the state and practicing in the relevant specialty area elect to participate. Id at $\$ 2976$.

The Oregon Basic Health Services Act contains a similar provision that protects from "civil liability or professional disciplinary action" any health care provider who fails to provide a service to a Medicaid beneficiary that the legislature has chosen not to fund. $S 27, \S 10$, 66th Oregon Legislative Assembly (1991). An explanatory statement issued by the Senate President's office states that this "sets an important precedent ... if we hope to establish practice guidelines and parameters and then employ them without substantially increasing the risk of lawsuits." See also Brian McCormick, Defense Lawyers Raise Questions about Maine Parameters Project, Am Med News 1, 27 (May 6 , 1991) ("At least four proposals pending or introduced in Congress link the two concepts [of guidelines and tort reform]. Administrative rule-making processes in Massachusetts and New Jersey also have tied guidelines to liability, and California residents may consider a ballot proposal in 1992 that contains some elements of the Maine legislation."). 50)

71. For useful guides, see $A M .4$ Report (cited in note 6): Chassin, 25 Inquiry 437 (cited in note 
Medicare peer review statute has had no discernible effect, and (2) it is difficult to craft a statutory definition that will reliably distinguish between reputable organizations and procedures for practice policy development and those that do not deserve protection. ${ }^{72}$ The following analysis demonstrates that both of these obstacles can be surmounted.

1. The Failure of Malpractice Immunity for Medicare Peer Review Norms. Several analysts have remarked on the puzzling presence in the Medicare peer review statute of a sweeping malpractice immunity provision that has been completely overlooked by courts and defense counsel during its nearly twenty-year history: "[N]o provider . . . of health care services shall be civilly liable to any person under any [federal or state law] on account of any action taken by him in compliance with or reliance upon professionally developed norms of care and treatment applied by [a Medicare Peer Review Organization ('PRO')]." 73 This statute essentially accomplishes, in a narrower context, the result argued for here: it gives conclusive defensive effect $^{74}$ to PRO practice policies applied in the treatment of Medicare patients. Therefore, in order to argue successfully that this statute should be expanded to practice policies generally, one must explain how to overcome the failure of the PRO immunity provision. Closer examination reveals several flaws in the design and application of this statute that a properly crafted variable immunity provision could avoid.

One straightforward explanation for the failure of the PRO immunity statute is the absence of any relevant practice policies. ${ }^{75}$ As originally envisioned, Medicare peer review was supposed to rely heavily on specific

72. Also, Clark Havighurst argues that professionally generated standards should not control because they are not likely to represent the socially optimal balance between quality and the cost of care. Clark C. Havighurst, The Professional Paradigm of Medical Care: Obstacle to Decentralization, 30 Jurimetrics J 415 (Summer 1990); Clark C. Havighurst, Practice Guidelines for Medical Care: The Policy Rationale, 34 SLU L Rev 777 (1991). Indeed, given the AMA's explicit insistence that cost should not be a factor in practice policy development, there is good reason for this concern. See text at note 28. However, the overly protective nature of professional standards weighs against their use in establishing negligence, not in negating it. That professional groups may be too concerned about quality provides an additional margin of confidence that doctors who comply should not be found liable. Therefore, Havighurst's criticisms fail to recognize the important distinction between the offensive and the defensive use of practice policies.

73. 42 USC $\$ 1320 \mathrm{c}-6(\mathrm{c})$ (1982). This provision was enacted in 1972, with the creation of the Professional Standards Review Organization ("PSRO') program, the predecessor to the existing Peer Review Organizations ("PROs"). PROs are charged with monitoring the care rendered to Medicare beneficiaries to determine whether it meets acceptable standards of quality, without being wasteful.

74. The legislative history clarifies that this provision "is not intended to create a legal presumption of liability" for doctors who do not follow such norms, and therefore does not give them any offensive effect. S Rep No 92-1230, 92d Cong. 2d Sess 267 (1972).

75. Peter Mellette, The Changing Focus of Peer Revitu L'nder. Medicarr, 20 U Richmond L Rev 315 , 330-31 (1986). Another explanation is that compared to the population at large. elderly patients bring fewer malpractice actions because of their relative lack of access to legal services, as well as the effect that their shortened life spans have on the damages prospects and the lessened incentive for plaintiff's' lawyers to accept their cases for a contingent fee. See Marshall Kapp. The Malpractice Crisis: Relevance for Geriatrics, $37 \mathrm{~J}$ Am Geriatrics Soc 364 (1989); Rand Rosenblat,. Rationing "Normal" Health Care: The Hidden Legal Issues. 59 Tex L Rev 1401, 1415 (1981) (discussing reasons Medicaid patients bring fewer malpractice suits). 
treatment policies promulgated in advance. These practice policies were to emanate from a national council but be tailored to local conditions. They were to be based on existing practice patterns and adjusted for responsible fiscal considerations. Also, they were to be designed to eliminate most of the subjectivity from the review of the necessity for covered services in individual cases. $^{76}$

Very little of this came to pass. PROs use practice norms primarily as screening devices to flag aberrant cases, which are then submitted to subjective evaluation by physician reviewers. ${ }^{77}$ These screening criteria are poorly disseminated and are not written in a manner that is useful for instructing practicing doctors about appropriate treatment in particular clinical situations. ${ }^{78}$ For example, the following are included among the "generic quality screens" all PROs must use to flag cases for further review: blood pressure, temperature, or pulse beyond a specified range at the time of patient discharge, any fluids or drugs administered on the day of discharge, any death following surgery, nosocomial infection, or physical injury while hospitalized. These conditions do not instruct physicians in advance how to treat patients, nor does their presence necessarily indicate substandard care. Instead, "these screens are only generic and will require further qualification

76. See Alice C. Gosfield, PSROs: The Law and the Health Consumer 34-37 (Ballinger, 1975). As Congress explained at the time of passage,

the review process would be made more sophisticated through the use of professionally developed regional norms of diagnosis and care as guidelines for review activities, as opposed to the present usage of arbitrarily determined checkpoints. The present review process, without such norms, becomes a long series of episodic case-by-case analyses on a subjective basis which fail to take into account in a systematic fashion the experience gained through past reviews or to sufficiently emphasize general findings about the pattern of care provided.

S Rep No 92.1230 at 257 (cited in note 74).

77. As explained by Professor Jost, "once problems are identified by nurse reviewers, physician reviewers apply their own judgment, using implicit unarticulated standards . . . . Because of the potential subjectivity of this system, PROs rely heavily on repetitive review to assure accuracy and fairness." Timothy Jost, Administrative Law Issues Involving the Medicare Vitilization and Quality Control Peer Review Organization (PRO) Program: Analysis and Recommendations, 50 Ohio St L. J 1, 21 (1989). The abandonment of standards in the review process is reflected in proposed amendments to the PRO regulations, which would delete all reference to the use of standards since "PROs do not apply standards in the conduct of review and do not routinely develop written standards or variant standards apart from those included in [screening] criteria." 53 Fed Reg $\$ 8654,8660$ (1988) (proposing to amend 42 CFR $\$ 100$ ). See also Dep't of Health and Welfare. Professional Standards Revieu Organization: 1978 Program Evaluation 246 (January 1979) ("Site assessment teams have regarded the establishment of areawide norms and criteria as a general problem. Specified criteria are not strictly adhered to, nor are areawide norms currently being utilized in fourteen of the eighteen [surveyed] PSROs.").

78. See Jost, 50 Ohio St L J at 9-19, 22-24, 28-30 (cited in note 77); Edward Hirshfeld, Medically Unnecessan Denials: Where the Standards Come From and How Physicians Can Participate, $262 \mathrm{~J}$ Am Med Ass'n 3187 (December 8, 1989).

Unless PSRO standards are both specific and encompassing and constitute a codification of the standard of care rather than merely review screening criteria, the immunity provision is meaningless. Screening criteria, though acceptable for Medicare or other claims payment determination, are unlikely to be sufficient when the issue is judging whether an adequate standard of care has been met.

Note, PSRO: ./alpractice Liability and the Impact of the Civil Immunity Clause, 62 Georgetown L J 1499, 1506 (1974) (authored by Kenneth W. Kleinman). 
on an individual case basis."79 Therefore, they are not designed or available for setting a standard of care in litigation. ${ }^{80}$ These flaws presumably will not exist, at least to the same degree, in practice policies developed as part of the current movement.

The second explanation for the failure of the PRO immunity provision is the poor drafting of the statute. Several commentators have observed that immunity is undermined by the statute itself, ${ }^{81}$ which peculiarly conditions protection from malpractice on doctors' adherence to a standard of "due care" in following a PRO norm. ${ }^{82}$ This self-contradictory construction has produced unresolved and sometimes incomprehensible debate over precisely what the statute was intended to do. Moreover, the statute's opaque reference to "norms" does not lend itself to easy application in light of the regulatory definition of this and similar terms, which seems to offer the nonsensical construction that immunity is available simply by practicing at the arithmetical median of existing practice patterns. ${ }^{83}$

79. William P. Hittel, PRO Experiences at a Florida Community Hospital, 44 Am J Hosp Pharm 88, 90 (January 1987).

80. These screens are based primarily on statistical compilations of existing practice patterns. However, as a leading decision explains, it is an "incorrect notion that the standard for malpractice is to be determined by a poll of the medical profession." Hood v Phillips, 554 SW2d 160, 165 (Tex 1977). Instead, the question is whether the profession considers the practice appropriate or respectable, an evaluation that Medicare peer reviewers make independently of screening criteria.

81. At one extreme, commentators argue that the PRO statute has never been applied because there is, in effect, no immunity at all. See, for example, E. Haavi Morreim, Cost Containment and the Standard of Medical Care, 75 Cal L Rev 1719, 1752 (1987) ("This 'due care' requirement essentially reinstates the common law standards of liability."). But it is absurd to believe Congress intended to undercut the immunity so thoroughly in the same act that created it. Alternatively, it is perfectly conceivable that Congress meant to distinguish between liability for the choice of procedures and liability for the care with which chosen procedures are performed, immunizing the former but not the latter. Randall R. Bovbjerg \& William Kopit, Coverage and Care for the Medically Indigent: Public and Private Options, 19 Ind L Rev 857, 916 (1986) ("Through an unfortunate linguistic coincidence, the legal standard of 'care,' which originally meant the degree of carefulness required to be nonnegligent, has come to mean also what services themselves are appropriate."). Indeed, Morreim herseif later advances this very distinction as central to malpractice theory. See E. Haavi Morreim, Stratified Scarcity: Redefining the Standard of Care, 17 L Med \& Health Care 356, 359-60 (1989). But this reading is undercut by the legislative history, which indicates that the due care proviso is intended to reach physicians who "misapply" a norm. S Rep No 92-1230 at 267 (cited in note 74). Therefore, after numerous analyses, no coherent construction of the statute has emerged. See generally J. Blum, P. Gertman \& J. Rabinow, PSROs and the Law 166 (Aspen Systems Corp, 1977); Alice C. Gosfield, Medical Necessity in Medicare and Medicaid: The Implications of PSROs, 51 Temple L Q229, 23638 (1978); Joseph H. King, In Search of a Standard of Care for the Medical Profession: The "Accepted Practice" Formula, 28 Vand L Rev 1213, $1271-74$ (1975); Note, 62 Georgetown L. J at 1506 (cited in note 78); Note, Federally Imposed Self-Regulation of Medical Practice: A Critique of the Professional Standards Review Organization, 42 Geo Wash L Rev 822, 838-41 (1974) (developed by Doctor Michael Rapp); Note, Professional Standards Review and the Limitation of Health Services: An Interpretation of the Effect of Statutory Immunity on Medical Malpractice Liability, 54 BU L. Rev 931, 936-38 (1974) (authored by Leah S. Crothers); Clark C. Havighurst \& James F. Blumstein, Coping with Quality/Cost Trade-Offs in Medical Care: The Role of PSROs, $70 \mathrm{Nw}$ U L Rev 6, 40-44 (March-April 1975).

82. The statute contains the following provision immediately following the portion quoted earlier (see note 73 and accompanying text): "but only if [the provider] exercised due care in all professional conduct taken or directed by him and reasonably related to, and resulting from, the actions taken in compliance with or reliance upon such professionally accepted norms of care and treatment." 42 USC $\$ 1320 \mathrm{c}-6(2)(\mathrm{c})(2)$ (cited in note 73 ).

83. The PRO regulations, like those of the earlier PSRO scheme, distinguish between "norms," which are statistical measures of existing patterns of practice, and "criteria" and "standards," which 
It is also probable that the general collapse of Medicare peer review as a mechanism for controlling utilization has contributed to the immunity provision languishing in obscurity ${ }^{84}$ The statute was subjected to an allfronts barrage by organized medicine's biggest guns. The AMA challenged the statute's constitutionality in court, mounted sustained pressure in Congress for its repeal, and encouraged entrenched resistance to participation at a local level. 85 "Over four years after the law's enactment, a little more than half of the 203 local PSRO areas had an organization actually engaged in some form of PSRO review." 86 Funding was severely cut in 1975, and the program was almost repealed in 1981.87 Although it was revived in 1982 , it survives only in a modified form, tailored to meet the particular requirements of monitoring care under a prospective payment form of reimbursement. ${ }^{88}$ The new $\mathrm{PRO}$ program makes much greater use of generic screens than before, but, as described above, these still occur in a retrospective rather than prospective setting. ${ }^{89}$

It is possible that doctors were so antagonistic to Medicare peer review and the very concept of practice standards that they refused to embrace them even in their own defense. ${ }^{90}$ This speculation is supported by the fact that, at one stage, the AMA actually called for the repeal of the immunity provision out of concern that it might encourage doctors to abide by these illicit standards. ${ }^{91}$ Since then, however, professional medicine has undergone a

are qualitative expressions of the appropriate range of care. 42 CFR $\$ 466.1$, 466.100; Gosfield, PSROs: The Law and the Health Consumer (cited in note 76); Jost, 50 Ohio St L J at 21 (cited in note 77). A literal application of these definitions produces an absurd reading of the immunity statute; therefore, the statutory reference to "norms" is probably intended as a generic reference to criteria and standards as well. Still, as noted above, the practical reality is that PROs have developed only the statistical screens.

84. See generally Congressional Budget Office, The Effect of PSROs on Health Care Costs: Current Findings and Future Evaluations (June 1979); James F. Blumstein, The Role of PSROs in Hospital Cost Containment, in Micheal Zubkoff, Ira Raskin \& Ruth Hanft, eds, Hospital Cost Containment: Selected Notes for Future Policy 461, 472-73 (Prodist for Milbank Memorial Fund, 1978)

85. Gosfield, 51 Temple $\mathrm{L} Q$ at 230-31 (cited in note 81); Note, PSRO: A Status Report on Medical Peer Review Under the 1972 Social Security Act Amendments, 6 Loyola U Chi L J 90, 103 (1975)(authored by Marilyn Kuhr)

86. Gosfield, 51 Temple $\mathrm{L} Q$ at 231 (cited in note 81 ).

87. Id; Helen L. Smits, The PSRO in Perspective, 305 New Eng J Med 253 (1981).

88. Mellette, 20 U Richmond L Rev at 334-36 (cited in note 75).

89. See notes $77-80$ and accompanying text.

90. See Gosfield, PSROs: The Laul and the Health Consumer at 29 (cited in note 76) ("The concept of norms ... has been the most controversial element of the PSRO program, presenting the greatest obstacle to the program's acceptance by physicians."); Note, 6 Loyola U Chi LJ at 102 (cited in note 85):

Physician feeling against the PSRO law has run high. [Physician concerns] include fear of the nationalization of medicine and the specter of a socialist government controlling physician behavior; disruption of the physician-patient relationship; violation of patient rights to privacy and confidentiality; lowering of the quality of health care; stratification of standards into "cookbook medicine"; subpoena or discovery of PSRO records; abuse of HEW's power to examine records and inspect facilities: loss of income to providers of care; and lack of due process in statutory purposes and procedures.

91. Gosfield, 51 Temple L $Q$ at 253 n52 (cited in note 81) (quoting Congressional oversight hearings, where the AMA maintained that "this provision could have the unintended and undesirable effect of pressuring practitioners to adhere to norms"). 
dramatic reversal. The AMA and the various specialty societies now enthusiastically embrace the concept of practice parameters, at least as long as they themselves are in charge of parameter development. ${ }^{92}$ Therefore, the prospects for a properly drafted immunity statute are now much improved.

2. Disputes Over the Reputability of Practice Policies. The prospect formal practice policies hold for malpractice reform is that they will simplify the determination of medical custom and weed out cases where a plaintiff's expert presents merely an alternative practice philosophy rather than a legitimate attack on the credibility of the defendant's professional judgment. Practice policies cannot achieve their full potential, though, unless their reputability is beyond dispute. If there is any basis for challenging the reliability of the procedures the issuing organization uses to formulate policies, or the authoritativeness of the organization itself, then the case is thrown back into a factual dispute that leaves the jury in the position of arbiters of the ultimate standard of care.

One ready legislative solution would be to promulgate a list of qualified standard-setting agencies. However, this approach is cumbersome, since which entities should be included would turn on a consideration of how they go about adopting standards, the purpose for which they adopt standards, and what interest groups or portions of the profession they represent. My proposal avoids these difficulties by leaving the initial determination of reputability to the trial judge. It would convert the "respectability" component of the respectable minority rule, in cases where there is no genuine dispute, from a question of fact to a question of law.

Legislatures might designate some organizations and procedures as qualified per se, ${ }^{93}$ but other practice policies would be eligible for the same protections if they met the existing legal concept of respectability. The indefiniteness of this term should be greatly reduced through a judicious application of precedents. At the very least, the determination will be more carefully targeted by focusing on the respectability of the issuing organization and its process of promulgation, separately from the inherent appropriateness of the standard itself.

Judges are likely to encounter a number of recurring contentions in determining respectability. ${ }^{94}$ First, plaintiffs will argue that standards set by insurers should not be honored because they are driven by cost concerns, not

92. See notes $27-34$ and accompanying text.

93. For instance, the legislature may need to declare that an otherwise valid practice policy remains authoritative for a specified number of years, perhaps five. After that, a standard, even though it was thoroughly considered when adopted, becomes subject to question and will quickly lose its authoritative status if it is not regularly reviewed and updated. The legislature would also have to consider whether new standards apply retroactively or only to disputes that arise after their adoption.

94. The fact that these objections are generic provides additional support for shaping the law through judicial precedents and legislative direction rather than by jury discretion. 
by optimal patient care. Such contentions should be viewed skeptically. ${ }^{95}$ Socially optimal care requires a tradeoff between costs and benefits, ${ }^{96}$ a tradeoff insurers are more likely to make than professional groups. Whether a reasonable tradeoff exists in a particular standard is not for the courts to determine de novo, because this balance implicates the ultimate question that malpractice theory relegates to determination by medical custom. ${ }^{97}$ Instead, the only inquiry for the court should be whether there is sufficient social acceptance of the tradeoff to indicate its respectability. This acceptance should be evident if a sizeable number of patients and physicians agree to be bound by the standard by choosing to enroll with or work under the particular insurance plan. 98

Thus, just as the law currently adjusts the standard of care according to the specialty to which a doctor adheres, it should tailor its recognition of respectable standards according to the patient's or society's choice of how much money to spend. ${ }^{99}$ In the past, malpractice law relied on a marketplace of ideas to determine the medically ideal standard of care; if the particular procedure or school of practice lost credibility within the community of professionals, it was largely abandoned and so lost the protection of medical custom. ${ }^{100}$ As cost constraints exert themselves with greater force, the same dynamic will play out in the community of payers and patients, as well as professionals, who abandon specific procedures (or substitute new ones) for financial reasons. However, the balance struck will now be more truly

95. These comments are restricted to whether a malpractice action should lie against particular practitioners who follow a practice policy. Whether the organization that adopts the policy should be exposed to liability for the judgment it makes is a separate issue I do not purport to address here. See Wickline v State, 192 Cal App3d 1630, 239 Cal Rptr 810 (1986), holding that negligent utilization review decisions may expose payers to liability for adverse outcomes that result from those decisions. Wickline did not address the physicians' liability because the patient chose not to sue them. Nevertheless, the decision might be read as stating in obiter dictum, contrary to my position, that cost-constrained guidelines should never take precedence over "pure" medical guidelines: "[T]he physician who complies without protest with the limitations imposed by a third party payor, when his medical judgment dictates otherwise, cannot avoid his ultimate responsibility for his patient's care. [I]t is essential that cost limitation programs not be permitted to corrupt medical judgment." Id at 1646, 239 Cal Rptr at 820. This is double dictum, however, not only because the physicians were not charged, but also because there was in fact no conflict between medical and payer judgment: "all the doctors who testified at trial, for either plaintiff or defendant, agreed that Dr. Polonsky's medical decision to discharge Wickline met the standard of care applicable at the time." Id.

96. Havighurst \& Blumstein, $70 \mathrm{Nw}$ UL Rev 6 (cited in note 81).

97. See Hall, $17 \mathrm{~L}$ Med \& Health Care at 351-52 (cited in note 2).

98. Again, the legislature might establish some numerical benchmark as per se respectableperhaps $10 \%$ of a relevant geographic market.

99. To make the analogy more explicit, patients who choose midwives for home birth cannot complain that the practice of midwifery is disreputable per se. Likewise, an HMO patient should not be allowed to complain that fee-for-service doctors would disagree with the HMO doctor's decision not to hospitalize, if this is a decision other HMOs would make, or, for a sufficiently large HMO, if it is a decision that the HMO routinely makes. For further development of these ideas, see generally id; Randall R. Bovbjerg, The Medical Malpractice Standard of Care: HMOs and Customary Practice, 1975 Duke L J 1375.

100. Eddy, $263 \mathrm{~J}$ Am Med Ass'n at 1265 (cited in note 7) ("The model is Adam Smith's 18th century marketplace. The 'invisible hand, which operates through individual decisions, can be counted on to sort everything out. Right ideas will thrive, wrong ideas will wither, and the collective medical consciousness will slowly converge on the correct policy."). 
reflective of the social optimum, since the marketplace at work will be one of costs and benefits.

A second recurring contention will be that the procedures used in promulgating practice policies were less than perfect. David Eddy has recently critiqued a variety of approaches used to develop practice policies, summarizing their strengths and weaknesses. ${ }^{101}$ Plaintiffs will seize on the weaknesses, and no practice policy will ever clearly pass muster as a matter of law. ${ }^{102}$ But, again, most of these disputes can be avoided. The courts should give the same deference to the process that an organization chooses for practice policy development as to the substance of the policy it generates, since both implicate directly the ultimate question of propriety, which malpractice theory intends courts to avoid. Both issues are subsumed within a determination of the issuing organization's respectability, and therefore it would be inappropriate to extract either for separate consideration, as long as the organization in fact reflects a consensus of opinion in one sector of the profession. At most, courts should ascertain only that the procedures followed are no worse than those the courts would use if they were to make the same judgments through expert witnesses-a review of the published literature and an opinion survey of selected authoritative physicians.

\section{The Specificity of Practice Policies}

In order for the proposed variable immunity standard to have much effect, however, practice policies must be both prescriptive and precise. Prescriptiveness exists when guidelines give mandatory instructions for concrete clinical situations in advance of treatment, rather than giving merely advisory statements or general screening or "flagging" criteria for use in retrospective review. Lack of prescriptiveness eliminates the relevance of practice policies to setting a standard of care. But prescriptiveness alone is not sufficient; precision is also essential, for without concrete identification of their boundaries, it is impossible to declare conclusively when practice policies govern and when they do not. To illustrate from the RAND project described at the beginning of the article, ${ }^{103}$ if certain defined indicators are deemed appropriate for a particular procedure (for example, unstable angina for coronary angiography), then there should be no liability for harm resulting from side effects of the procedure (assuming proper patient consent

101. Id at 1272; David M. Eddy, Practice Policies: Guidelines for Methods, 263 J Am Med Ass'n 1839 (1990). See also Marilyn J. Field \& Kathleen N. Lohr, eds, Clinical Practice Guidelines (Institute of Medicine, 1990). These approaches are: (1) gathering together a group of experts to generate a collective statement of their beliefs; (2) researching a consensus that emerges from existing empirical studies; (3) explicitly weighing the medical benefits and costs of the procedure in question against alternative practices; and (4) adding to the latter assessment a determination of patients' preferences for different outcomes.

102. Eddy explains that neither of the two generic approaches he considers optimal are followed systematically outside isolated research programs, because they involve very difficult and complex assessments of patient outcomes and preferences. Eddy, $263 \mathrm{~J} \mathrm{Am} \mathrm{Med} \mathrm{Ass'n} \mathrm{at} 1275$ (cited in note 7).

103. See notes $18-21$ and accompanying text. 
was obtained). Likewise, if other concrete indicators are deemed inappropriate for the procedure (for example, the patient has only congestive heart failure; angiography is not indicated), no fault lies in failing to perform it. However, where the indicators are deemed equivocal, the decision necessarily rests with the jury, informed by expert testimony tailored to the particular circumstances of the case (for example, the degree of angina, the success of medical intervention, the outcome of less invasive tests, local practices, and patient preferences).

Moreover, we must distinguish between the breadth of guidelines and their generality. It is possible to define a wide range of treatment options with a great deal of specificity. If practice policies are broad rather than vague, we will know their limits with precision and, at least for the treatment options contained within those limits, courts will be able to determine whether the defendant's conduct falls within a clearly allowable zone or within a grey area of acceptability. ${ }^{104}$

The difficulty encountered to date is that what might otherwise be sufficiently precise guidelines are rendered entirely advisory or equivocal by waffling phrases and general disclaimers. For instance, the anesthesiology standards described previously ${ }^{105}$ call for monitoring blood pressure and heart rate "at least every five minutes," but, "under extenuating circumstances, the responsible anesthesiologist may waive the requirement." These two qualifications render the standard incapable of offering a definitive statement of whether every five minutes is often enough or too often. Even more obvious is the Blue Cross/Blue Shield recommendation against routine hospital admission $\mathrm{x}$-rays "unless the medical history or symptoms and signs of chest disease in the judgment of the physician" call for one. ${ }^{106}$ Making

104. Again, the Coronary Angiography Guidelines are instructive. They divide various indications for the procedure into three classes: "conditions for which there is general agreement that [it] is justified," "conditions for which there is general agreement that [it] is not ordinarily justified," and "conditions for which [it] is frequently performed, but there is a divergence of opinion with respect to its justification in terms of value and appropriateness." Coronary Angiography Guidelines at 966A (cited in note 31). An example of the latter category is the use of coronary angiography for periodic evaluation of patients after cardiac transplantation. Id at $967 \mathrm{~A}$. Without some further indication of why opinions differ and who holds them, courts have little guidance in resolving a suit that falls into this category. But at least the guidelines are clear as to the propriety of testing, or not testing, for cases that fall within the first two categories.

It may be that the grey zone of acceptability is stated inconclusively because (1) there are different schools of practice; (2) the proper treatment varies too subtly to be captured in a standard; or perhaps (3) not enough is yet known about patient outcomes for there to be any degree of consensus. In the latter two cases, there is no choice but to try the issue. In the first case, it may be that falling into the "differing opinions" category conclusively establishes compliance with at least a respectable minority. This cannot be known, however, unless the practice policy makes this finding clear. In these situations, it would serve the courts much better to have separate practice policies from separate groups, each reflecting a firm opinion. See Havighurst, 34 SLU L Rev 777 (cited in note 72 ) (advocating much greater pluralism in the development of practice policies).

105. See notes 29-30 and accompanying text.

106. See note 23 and accompanying text. Similarly, the Coronary Angiography Guidelines, which otherwise are model practice policies, undercut their protective effect in litigation by including a general disclaimer at the outset that they are "not intended to provide strict indications or contraindications to coronary angiography because, in the individual patient, multiple other considerations may be relevant, including the family setting, occupational needs, and individual preferences 
these standards merely advisory deprives them of any relevance to malpractice litigation. But it is just this result that the AMA would accomplish for all practice policies by its suggestion that "parameters could include a disclaimer stating that they are not intended to displace the physician's discretion to conform treatment to the particular clinical circumstances of the individual patient."107

The AMA is motivated by its concern that physicians cannot be restricted to one procedure or series of procedures for a specific condition: "No two patients are exactly alike and no two conditions are exactly alike." 108 But it is this "snowflake" theory that wreaks havoc with the custom-based standard in malpractice to begin with. It is impossible for physicians to have both wide clinical discretion and, at the same time, freedom from scrutiny in malpractice litigation, nor is it appropriate to make an across-the-board choice between these two extremes. Where the science is clear, there should be a single, national standard. Where there is more divergence of opinion, conflicting, but still respectable, standards will be seen. However, where either patient preferences or appropriate indicators are too variable or subtle to capture in concrete standards, then it will be impossible to define proper clinical conduct with precision. ${ }^{109}$ Treatment decisions in such circumstances will necessarily be questions of judgment-judgment which can be exercised negligently, yet which medical custom does not resolve. This leaves no alternative but for the jury to resolve the issue by reconciling the competing testimony.

This is not to say that the AMA's "snowflake" concerns have no legitimacy. Indeed, I have previously written that, as a result of "the intensely judgmental, individualistic, uncertain, and humane nature of health care, . . . [d]etailed standards are capable of covering only a very limited part of the

concerning lifestyle." Coronary Angiography Guidelines at 946A (cited in note 31). Plaintiffs' lawyers will leap on statements such as this to create a jury question as to whether the doctor should have departed from the guidelines. While it is appropriate to recognize that guidelines always may be overridden by the patients' informed refusal of treatment, such general disclaimers are not necessary if, as in this case, the guidelines themselves incorporate specific social factors where appropriate. To illustrate, the coronary angiography guidelines call for testing of asymptomatic patients with prior heart disease even if they are not presently at high risk if their "occupation involves the safety of others, for example, airline pilots, bus drivers, [etc., and] in certain occupations that frequently require sudden vigorous activity, for example, firefighters, police officers, athletes." Id at 966A. See also Chassin, $258 \mathrm{~J} \mathrm{Am} \mathrm{Med} \mathrm{Ass'n} 2533$ (cited in note 19) (considering effect of angina on occupational and lifestyle functioning).

107. Am Med Ass'n, Legal Implications of Practice Parameters Part One, 23 (Am Med Ass'n, 1990) (report to the PPRC). In like manner, the AMA recommends that practice policies contain the following disclaimer:

Adherence to these parameters is voluntary. [T] hese parameters should not be considered inclusive of all proper methods of care or exclusive of other methods of care or exclusive of other methods of care reasonably directed to obtaining the same results. The ultimate judgment regarding the propriety of any specific procedure must be made according to the best medical judgment of the physician in light of the individual circumstances presented by the patient.

Id at Part Three, 17.

108. Interview with James $S$ Todd, Am Med News 15 col 1 (cited in note 28).

109. See generally Eddy, 263 J Am Med Ass'n 1839 (cited in note 101). 
medical treatment terrain."110 But the judgment of how general or specific to make guidelines must be based on the state of the science, not on the state of the law or on any a priori notion that physicians' clinical discretion must be saved at all costs. ${ }^{111}$

\section{$\mathrm{V}$ \\ Conclusion}

By leaving the medical profession free to determine itself what constitutes proper standards of care, the law strives to be neutral with respect to how medicine should be practiced. The legal system may have major failings in achieving this ambition, but formal practice policies have the potential to correct these failings. Whether this potential is large or small depends on two factors: the nature of malpractice allegations and the nature of practice policies. A practice policy, however rigorous, is of no use if the nature of the claimed error is either incorrect performance of the treatment in question or failure to recognize which practice policy applies by virtue of a failure in diagnosis. Where, however, the patient alleges the incorrect choice of a treatment plan for a condition or symptom properly diagnosed, a precise and prescriptive practice policy is capable of conclusively resolving disputes over the applicable standard of care. For this potential to be realized, though, physicians must yield some measure of their clinical freedom, where this is warranted by the state of the science. Crafting practice policies with a view toward preserving complete clinical discretion would only perpetuate the law's contamination of medical practice.

110. Hall, 137 U Penn L Rev at 479 (cited in note 26). However, I have also written that "while there may be an irreducible intuitive core to medical practice, the domain that belongs to art has been artificially inflated to preserve physician autonomy. It is possible and desirable to bring greater definition and certainty to much of medical practice." Id at 478 . For further discussion of the degree of specificity possible in practice guidelines, see Chassin, $258 \mathrm{~J}$ Am Med Ass'n 2533 (cited in note 19).

111. Meyer, Am Med News 36 (cited in note 3) (". "If the data [are] really firm, the guidelines should be strict. Where the data [are] loose, the guidelines should be loose." ") (quoting John Ball, M.D., executive vice president of the American College of Physicians). 
